\title{
Stilistic analysis and social value in andrea hirata's novel ordinary people (review through a literature sociology approach)
}

\author{
Jenumi Faidis $^{1}$, Missriani ${ }^{2}$, Yessi Fitriani ${ }^{3}$ \\ ${ }^{1}$ SMPN 1 Rambang \\ ${ }^{2}$ Universitas PGRI Palembang
}

\begin{tabular}{l} 
Article Info \\
\hline Article history: \\
Received Jul $18^{\text {th }}, 2021$ \\
Revised Aug $12^{\text {th }}, 2021$ \\
Accepted Aug $30^{\text {th }}, 2021$ \\
\hline
\end{tabular}

\section{Keyword:}

Novel

Stylistics

Diction

Figurative

Social values.

\begin{abstract}
Stylistic Analysis and Social Values in Andrea Hirata's novel Orang-Orang Asli (Review Through the Sociology of Literature Approach) is an analysis of the use of language and the relationship between literary works and society in the novel. This research is a descriptive qualitative study with the aim of describing the uniqueness and selection of vocabulary, particularly the use of diction (choice of words), figurative meaning (figurative meaning) and social values contained in the novel Orang-Orang Asli by Andrea Hirata. The data of this research are in the form of lingual units which contain unique vocabulary and morphosyntax as well as uniqueness of language style and social values. Data collection techniques using library techniques, observe and take notes. Data analysis techniques are flow analysis which consists of four activities that occur simultaneously, namely data collection and classification, data reduction, data presentation, and drawing conclusions. Furthermore, this study uses the theoretical triangulation method, meaning that the discussion of the problem is the discussion of the problem by using some data to obtain the same data. The results of this study indicate that the use of diction or choice of words in Andrea Hirata's novel Orang-Orang Asli is (1) denotation meaning, (2) connotation meaning, (3) synonymous words (4) antonyms (5) concrete words, (6) Abstract, (7) general words (8) special words (9) straightforward words, (10) narrowing and broadening of the meaning (11) active words and (12) amelioration and peryorasi words. Utilization of a figurative language style that is unique and creates aesthetic effects on readers, namely metaphor, simile, metonemia, synekdoke, allegory, climax and correction. The social values contained in the novel Orang-Orang Asli by Andrea Hirata are the social values of love which include love and affection, help to help, devotion, care. The value of responsibility includes empathy, discipline. Life harmony values include obligation, tolerance and cooperation. The analysis above shows that the writer is able to highlight the uniqueness of the selection and use of specific vocabulary and figurative language which is aesthetically pleasing and has social values. This uniqueness is motivated by social and educational factors of the author. This has resulted in a distinctive style that has become a special characteristic of Andrea Hirata in expressing his ideas through the novel Orang-Orang Asli.
\end{abstract}

(C) 2021 The Authors. Published by IICET.

This is an open access article under the CC BY-NC-SA license

(https://creativecommons.org/licenses/by-nc-sa/4.0

\section{Corresponding Author:}

Jenumi Faidis

SMPN 1 Rambang

Email: jenumif@gmail.com 


\section{Introduction}

Literary works are born in the midst of society as a result of introductory imaginations and reflections on the surrounding social phenomena. Therefore, the presence of literary works is part of people's life. The author tries to produce his world view of the social reality around him to show that a literary work is rooted in a certain culture and a certain society.

The above statement actually implies that literature is a social institution that voices the world view of its author. This world view is not merely a direct empirical fact, but is an idea, aspiration and feeling that can unite the social groups of society.

The Novel of Common People is the latest work by author Andrea Hirata. This novel was published in February 2019 by the publisher Bentang Pustaka. Andrea Hirata's previous novels such as Laskar Pelangi (2005), Sang Pemimpi (2006), Edensor (2007), Maryamah Karpov (2008), Padang Bulan (2010), Cinta Dalam Gelas (2010), Eleven Patriot (2011), Ayah (2015) ), and Tree Circus (2018). Andrea Hirata's previous novels tell about marginalized people. Like other novels by Andrea Hirata, the novel Orang-Orang Biasa also tells about marginalized people who are inspired by true stories.

Andrea Hirata's previous novels mostly tell about education and the lives of marginalized people. However, Andrea Hirata's novel Orang-Orang Asli presents a different story. In the novel Orang-Orang Biasa, Andrea presents story content that contains elements of crime. This criminal act is a robbery committed by a character in the story. The following is a description of the crime in the novel.

"As for the ten losers, who have been preparing to rob, countless meetings, countless cups of coffee and boiled cassava has been brushed, dozens of robbery instances have been watched on DVD, circling practicing running until they enter the alley. market alley, when tomorrow will act "[1]. Reading the title of Ordinary People, the idea arises that the contents of the novel's story are novels that are about ordinary people. But Andrea Hirata turned Ordinary People into ordinary people with extraordinary minds. They are presented as figures who come from ordinary society with ordinary economics and ordinary knowledge.

Then they carried out a robbery in an area that was the setting for the story in the novel Orang Orang Asli. The robbery is the main conflict in the novel. The robbery was carried out to help pay tuition fees for one of the leading children. After successfully robbing hundreds of millions of dollars, they did not use the money. They returned the money from the robbery to the police.

Talking about novels, novels are literary works that contain stories that take a long time to read. Novels usually tell stories of sadness, joy, disappointment, life struggles, romance and so on. Therefore, in the novel there are characters to tell the atmosphere. These characters reinforce the contents of a novel. One of the characters in the novel is the main character. The main character is a person who plays a lot in the novel. The contents in the novel can be in the form of actual community situations, there are also mere fictional stories, it can also be stories of other communities. One of the contents in the novel is conflict. Conflict is a problem faced by the characters. The conflicts experienced in the novel are not much different from conflicts in society. For example conflicts about love, family, society and so on.

The presence of writers in the world of literature is inseparable from the literary works he creates. How far his works have an advantage over other writers' works and how high the responses of literary critics and researchers are. There are many literary works that are able to provide something unique, distinctive, and special in the realm of literature so that they are interesting to be used as objects of literary study or objects of study in various literary forums, including the study of stylistics.

Stylistics comes from English, namely "Style" which means style and from borrowed language "linguistic" which means grammar. According to the Indonesian dictionary, stylistics is a language science that studies language styles. Stylistics also means a study of how the author uses the sign system in line with the ideas to be conveyed from the complexity and richness of the constituent elements which are the target of study only in the form of using the sign system.

Stilistics examines literary discourse with a linguistic orientation, that is, it examines how writers manipulate the potentials and rules contained in language and give certain effects [2], stylistics is (1) a science that investigates the language used in literary works, (2) interdisciplinary science between linguistics and literature, and (3) the application of linguistics to language style research.

Stylistics is not only the study of language styles in literature, but also the study of language styles in general even though there is special research on literary language, as has been suggested. Language almost 
always has variations due to certain environments. It can also mean that stylistics is a stylistic study that suggests a form of science or at least a methodical study. Stylistic studies are based on the form of expression, form of class language and aspects of sound. However, 7 stylistic terms are generally known as the study of the use of language in literary works. The reasons for the use of language in literary works are because language is able to present a wealth of meaning, is capable of causing endless mysteries, is capable of causing emotive effects to readers or listeners, certain images and atmosphere. This disclosure is done by the author to show the nature of his creativity and the expression of these ideas is individual, personal that cannot be imitated and there is always renewal. Each author in making a work will show the use of language with its own characteristics and patterns that differentiate it from other authors. The use of distinctive language in his works will certainly show the characteristics of individualism, originality and style of each author. One of the peculiarities of the use of this language, among others, is shown by Andrea Hitara in his novel Orang-Orang Biasa.

Each author has a different concept in producing a literary copyright. This is due to the diversity and style of each author. Andrea Hitara's diversity and style through the novel Ordinary People, is very necessary and interesting to research. The novel is riddled with conflict, written in a realist style, studded with bold, unusual and unexpected, yet immensely compelling, metaphors.

The stylistic analysis in this study is intended as a part of linguistic studies. In principle, the focus of stylistics is language style, which is the method used by someone to express his meaning by using language as a means. This is quite reasonable if the author conducts a linguistic study in order to find and describe the meaning of the use of the language of Andrea Hitara's novel Orang-Orang Biasa, especially regarding vocabulary or diction. Apart from that, study the linguistics here too to find out the meaning of the use of figurative language styles found in the novel Orang Ordinary.

Stylistics is a science that investigates the use of language in literary works by considering the beauty of its aspects. This field is focused more on linguistic studies, which makes stylistics inseparable from literary theories. So far, literary language is more often used in stylistic studies. Even according to extended understanding, the way to express the theory and methodology of analysis in a literary text is through stylistic studies. One of the goals of this science is to explain and explain the function of something, in this case the beauty of using linguistic forms in a text. It can be from the aspects of figurative language, rhetoric, lexical and even grapology. Andrea Hirata's novel Orang-Orang Asli is full of this linguistic aspect.

It is not enough for a community group to be viewed from a geographical area, but every form of community unity has a certain system, that system is a social value. Social values related to social interaction in social life [3]. Many things are regulated in social values, even someone who violates them is subject to sanctions for their actions. So, it can be said that social values are values upheld by the community who wear them.

Literature is also a means to achieve certain values or ideologies in the reading community [4]. One of the modern literary works that refers to reality and contains social values is a novel.

\section{Method}

Descriptive method is used in examining the state of something and aims to describe it systematically, factually, and accurately through facts, characteristics and relationships between the phenomena under study. [5], "qualitative descriptive method means analyzing the form of description, not in the form of numbers or coefficients about the relationship between variables. Qualitative research involves ontology. The data collected are in the form of vocabulary, sentences and pictures that have meaning. Data collection steps in this study: 1) Library technique, the researcher reads the novel Orang-Orang Asli by Andrea Hirata, as a whole. 2) Watch and note techniques. After reading the research, the researcher listens to Andrea Hirata's novel OrangOrang Biasa to obtain data. Then the data obtained is recorded according to the needs in the study. [6] the analysis consists of four activities that occur simultaneously, namely: (1) data collection and classification (2) data reduction (3) data presentation (4) drawing conclusions / verification.

\section{Results and Discussions}

\section{Diction in the Novel of Ordinary People by Andrea Hirata}

Diction is the right choice of words, both in words, phrases and in sentences to convey ideas and the ability to find forms that suit a situation so that they have a certain effect. The vocabulary used in Andrea Hirata's Novels of Ordinary People is of many kinds. The use of diction or word choices that are widely available in 
Andrea Hirata's novel Orang-Orang Asli, includes (1) denotation meaning, (2) connotation meaning, (3) synonymous words, (4) antonyms, (5) concrete words, (6) Abstract, (7) Common words, (8) Special words, (9) Straightforward words, (10) Narrowing and broadening of meanings, (11) Active words, (12) Amelioration and penyorasi words.

\section{Figurative Meaning (figurative meaning) in Andrea Hirata's Novel of Ordinary People}

The figurative meaning (figurative meaning, transfered meaning) is the use of lexemes with meaning that is not true. For example the phrase 'women's crown' is not interpreted as a menda worn by a woman on her head which is a symbol of a leader and is decorated with gold or jewels, but this phrase is interpreted as 'woman's hair' besides that figurative meaning can also be found in proverbs or parables. . The figurative meanings in Andrea Hirata's novel Orang-Orang Biasa are as follows:

"Wherever Nihe blows, there Junilah, come along too." (OOB, 2019: 9).

The quote above means that the number is a person who is not firm. Other figurative meanings can also be found in the following quote:

"There were no waves, no wind. Debut Awaludin faced the homeroom teacher and asked to be moved his seat to the back." (OOB, 2019: 16)

The quote above means that there are no waves, no wind, meaning there is no cause / suddenly his seat was moved backwards. Other figurative meanings can also be found in the following quote:

"Every day Bastardin and Boron become more brutal towards Salud because they believe in the mythical assumption of a few hicks that the more demons a person faces, the more demonic in character they are." (OOB, 2019: 20).

The quote above has a meaning that describes the nature / attitude that is both outside and inside. The figurative meaning is also contained in the following quote:

"And, you and your mother, one quarter of money! It's dark math! ”. (OOB, 2019: 44).

The figurative meaning of the quote above has the same or the same meaning and is no different, does not understand mathematics at all.

"What can I do, some people do judge a book by its cover." (OOB, 2019: 75).

The figurative meaning of the quote above means that judging a thing only from its outward appearance. The figurative meaning can also be found in the following quote:

"The proverb of a million people throughout that time is true. Where there is a will, there is a way." (OOB, 2019: 120).

The figurative meaning in the above quote means that someone who is willing to put in effort must have ease in facing difficulties. The figurative meaning is also contained in the following quote:

"Luck is unachievable, unfortunate cannot be denied, what he feared the most happened. The letter was no longer visible on the table in the living room. " (OOB, 2019: 215).

The figurative meaning in the above quotation means that the life in front of us is the secret of Allah, fortunately or unlucky, it often comes unexpectedly.

\section{Social Values in the Novel of Ordinary People by Andrea Hirata}

[7] states that social value consists of several sub-values, namely (1) loves (affection) which consists of devotion, helping, kinship, loyalty, and caring (2) responsiveness (responsibility) which consists of on the value of belonging, discipline and empathy; (3) life harmony, which consists of the values of justice, tolerance, cooperation and democracy. By looking at these sub-values, it is clear that social values are very important.

In connection with the above opinion in the analysis and discussion of social values in Andrea Hirata's novel Orang-Orang Asli, there is a limitation of social values only on the social sub-value of love (affection) which includes love and affection, help, devotion, care. Responsibility (responsibility), namely the value of empathy, discipline and life harmony, including the values of obligation, tolerance, and cooperation. Social values can be seen from the social interactions between the characters reflected in the novel. The following is an explanation of the results of the social value analysis in Andrea Hirata's novel Orang-Orang Biasa.

\section{Review through the sociology of literature approach}


[8] sociology of literature is an understanding of literary works by considering its social aspects. An understanding of the totality of the work accompanied by social aspects contained therein. In addition, an understanding of literary works is defined as well as its relationship with the community that is based on it. Sociology of literature is a dialectic between literature and society.

The sociology of literature is a literary value related to social values which serves as a teaching medium to teach its readers. In this connection several studies. The first is literature as his personal literature or author. The second is the view that literature is only a means of entertaining. The last three views are that literature must teach or teach something. The social function of literature is related to social values. In this connection there are three things that must be considered: (1) the extreme point of view of the Romantics which considers literature to be equal to the work of priests or prophets. Therefore, literature must function as a reformer and reformer; (2) literature as entertainment only; (3) literature must teach something in an entertaining way.

From the description of the various theories above, the researcher analyzes Andrea Hirata's novel OrangOrang Biasa by using the sociology of literary works on social relations. These social relationships are established and formed through social interaction. In the process, this interaction will allow the continuity of the relationship between the main character and other characters. This relationship can be in the form of strife, romance, brotherhood and anything that includes social symptoms that occur in society in general.

Relationship of social values in the novel Orang-Orang Biasa by Andrea Hirata as teaching material in junior high school

The results of the research in the form of social values in the novel Orang-Orang Biasa by Andrea Hirata are implemented as teaching materials according to the basic competence of analyzing messages from a fiction book that is read. The core competencies and basic competences of Indonesian SMP are contained in Permendikbud Number 37 of 2018.

Media used in Andrea Hirata's novel Orang-Orang Asli. The material to be published on students is about messages in the form of social values from the novel. The results of the research on social values in Andrea Hirata's novel Orang-Orang Biasa will be implemented as teaching materials in the form of handouts. This can add to the variety in learning Indonesian, especially literature by directly studying literary works in the form of novels. Social values in the form of values of love, help to help, devotion, care, empathy, discipline, obligation, tolerance, cooperation. These values are usually often applied by students in the school environment.

\section{Conclusions}

The use of diction or word choices that are widely available in Andrea Hirata's novel Orang-Orang Biasa, includes (1) denotation meaning, (2) connotation meaning, (3) synonymous words, (4) antonyms, (5) concrete words, (6) Abstract, (7) Common words, (8) Special words, (9) Straightforward words, (10) Narrowing and broadening of meanings, (11) Active words, (12) Amelioration and penyorasi words. Figurative meanings (figurative meanings) are also found in Andrea Hirata's novel Orang-Orang Asli, as well as Metaphor, Simile, Metonimia, Sinekdoke, Allegory, Climax and Koreksio. The social values contained in the novel OrangOrang Biasa by Andrea Hirata consist of the social sub-value loves (affection) which includes love and affection for help, devotion, care. Responsibility, namely the value of empathy, discipline and life harmony, which includes the values of obligation, tolerance and cooperation.

\section{References}

Hirata, Andrea.2019. Orang-Orang Biasa. Yogyakarta: Bentang Pustaka.

Kridalaksana, Harimurti. 2013. Kamus Linguistik (edisi IV). Jakarta: PT Gramedia

Abdulsyani. 2012. Sosiologi, Skematika, Teori dan Terapan. Jakarta: Bumi. Aksara Algensindo

Wiyatmi. 2013. Sosiologi Sastra. Yogyakarta: Kanwa Publisher.

Aminuddin. 2013. Pengantar Apresiasi Karya sastra. Bandung: Sinar baru Budaya. Jakarta: Pustaka Pelajar.

Nazir. 2014. Metode Penelitian. Bogor: Ghalia Indonesia. Pustaka Utama.

Zubaedi. 2013. Pengembangan Masyrakat Wacana dan Praktis. Jakarta: P.T. Pajar Inter Pratama Mandiri.

Ratna, Nyoman, Kutha. 2013. Stilistika Kajian Puitika Bahasa, Sastra dan Budaya. Yogyakarta: Pustaka Pelajar. 
